\title{
The role of trauma experiences, personality traits, and genotype in maintaining posttraumatic stress disorder symptoms among child survivors of the Wenchuan earthquake
}

\author{
Yuwei Li, Qiuyue Lv, Bin Li, Dan Luo, Xueli Sun* and Jiajun Xu* (i)
}

\begin{abstract}
Background: Posttraumatic stress disorder (PTSD) is the most prevalent type of psychiatric disorder among children after an earthquake. This study investigated the role of trauma experiences, personality traits, and genotype in the maintenance of PTSD symptoms.

Methods: In a previous large-scale epidemiological investigation 1 year after the Wenchuan earthquake, 215 children with PTSD symptoms were selected at random with their blood samples collected. All of them were followed up, and their PTSD symptoms were assessed 3 years later. The adolescent version of the UCLA PTSD Reaction Index, the earthquake exposure scale, and the Junior Eysenck Personality Questionnaire were used to determine PTSD symptoms, trauma experiences, and personality traits, respectively. We sequenced candidate genes involved in the regulation of long-term potentiation via NMDA-type receptors to identify the related SNP variations.

Results: Being trapped for a longer period of time, feeling one's own or a family member's life to be in danger, losing a close family member or friend, extraversion, neuroticism, TrkB, G72 and CNTF were found to be associated with the maintenance of PTSD symptoms.

Conclusions: Experiences, personality traits, and genotype influenced the maintenance of PTSD in child survivors who were considered to be followed up without medicine. This result could help to identify potential targets for treatment and promote the rational allocation of medical resources.
\end{abstract}

Keywords: Posttraumatic stress disorder, Children, Earthquake, Personality traits, Long-term potentiation

\section{Background}

Earthquakes are one of the most unpredictable natural disasters and have a massive influence on the psychological and physical state of survivors. Posttraumatic stress disorder (PTSD) is the most prevalent type of psychiatric disorder among earthquake survivors, and it can be defined

*Correspondence: sunxuelihx@163.com; xujiajun120@126.com Mental Health Center, West China Hospital, Sichuan University, Chengdu, China

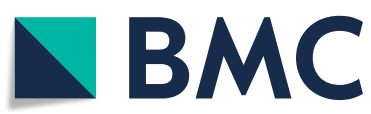

as delayed but lasting psychological stress disorder [1]. It is also a disabling disorder related to high comorbidity rates of depression, anxiety, and suicidal ideation [2]. Recent studies have suggested that the point prevalence rate of PTSD among child survivors after earthquakes is 12.4$28.4 \%$ [3-5], and trauma could have a lasting impact on children's developing brain and body [6].

Numerous empirical studies support the efficacy of trauma-focused psychological interventions $[7,8]$ and

(c) The Author(s). 2020 Open Access This article is licensed under a Creative Commons Attribution 4.0 International License, which permits use, sharing, adaptation, distribution and reproduction in any medium or format, as long as you give appropriate credit to the original author(s) and the source, provide a link to the Creative Commons licence, and indicate if changes were made. The images or other third party material in this article are included in the article's Creative Commons licence, unless indicated otherwise in a credit line to the material. If material is not included in the article's Creative Commons licence and your intended use is not permitted by statutory regulation or exceeds the permitted use, you will need to obtain permission directly from the copyright holder. To view a copy of this licence, visit http://creativecommons.org/licenses/by/4.0/ The Creative Commons Public Domain Dedication waiver (http://creativecommons.org/publicdomain/zero/1.0/) applies to the data made available in this article, unless otherwise stated in a credit line to the data. 
pharmacotherapy [9]. In clinical practice, people without treatment-seeking behavior [10] or enough medical care [11] have a limited chance of recovering from PTSD symptoms. Since the resources for intervention could be insufficient, it would be meaningful to investigate the maintenance factors for the PTSD patients who survived an earthquake and promote the rational allocation of medical resources.

Several studies have revealed that PTSD symptoms tend to heal spontaneously over time $[12,13]$. This process can be influenced by several factors that can only be assessed based on data about the long-term outcomes of PTSD without treatment. Although extensive research listed age, gender, posttraumatic growth, and other traumas as significant influences on the recovery process of children [14-16], few writers have been able to draw on any systematic research into the impact of various factors on the maintenance of PTSD in children.

Previously published studies on the onset factors of PTSD have confirmed the influence of trauma experiences, personality traits, and genotype $[4,17,18]$. However, the maintenance factors of PTSD are rarely systematically evaluated. Along with the continuity of the occurrence and development process, the elements that affect the onset may relate to maintaining PTSD symptoms, and exploring the influencing factors in the emergence of PTSD is vital for maintaining factors. Trauma exposure experiences outside the realm of daily life evoke fear, helplessness, and horror, and PTSD is a psychiatric disorder that develops after individuals suffer from life-threatening traumatic events [1922]. However, patients tend to manifest different symptoms of the disorder even after having the same experiences, which means that personality traits play an essential role in PTSD [23-25]. It is worth noting that the genotype is the same as personal traits among PTSD. In terms of molecular mechanisms, long-term potentiation (LTP) is dependent on NMDA receptors (NMDARs) in synapses, and it is the fundamental cellular correlate of learning and memory [26]. Synaptic plasticity, to which LTP pertains [27], plays a vital role in the developing brain and responds to a wide range of factors, such as life experiences [28]. All facts suggest that LTP is of concern in childhood. In addition, stress can impair LTP [29, 30], and the decrease in LTP induction in mice resulted in facilitated fear memories [31]. The findings of studies suggest that LTP takes part in the onset and maintenance of PTSD [32], and this process is adjusted by cytokines, such as BDNF and TrkB [26,33-35]. The investigation of the genotype of related cytokines will significantly increase our knowledge of LTP in PTSD.

On May 12, 2008, a devastating earthquake (measuring 8.0 on the Richter scale) struck southwestern China and caused the extensive onset of psychiatric disorders among the survivors [36]. The symptoms emerged weeks or months after the traumatic events, and even 3 years later, the prevalence of PTSD remained at 10.3\% [37]. Children were undoubtedly psychologically and physiologically affected by the earthquake. Due to the weak natural conditions and lack of local medical resources, it was difficult to provide effective treatment in time. The lack of treatment allowed the symptoms to run their natural course, and the follow-up of child survivors could fully assess the impact of various factors on the disease maintenance of PTSD. Accordingly, in this study, we aimed to investigate child survivors to explore the role of trauma experiences, personality traits, and genotype on the maintenance of PTSD symptoms. We hypothesized that trauma experiences, personality traits, and genotype are vital factors influencing the maintenance of PTSD symptoms, even when adjustments are made for other risk factors.

\section{Methods}

\section{Participants and procedure}

The children were recruited from schools in Qingchuan, Sichuan Province, from May to July 2009, approximately 1 year after the Wenchuan earthquake. The relatively stringent time horizon was executed because the manifestations in children would spontaneously change after the earthquake [38, 39]. A total of 20,749 children aged 7-15 years old in Qingchuan were thoroughly tested by the adolescent version of the UCLA PTSD Reaction Index, the earthquake exposure scale, and the Junior Eysenck Personality Questionnaire (JEPQ) by trained psychiatrists. According to the UCLA PTSD Reaction Index score, 3982 children had PTSD symptoms [4]. We randomly selected two villages out of the 31 townships in Qingchuan and recruited all the children with PTSD symptoms in the two towns as our subjects. A total of 215 children were selected, and there was no significant difference between the selection and nonselection groups. The blood of the selection group was collected at the beginning of their enrollment. After 3 years, all participants were then tested with the adolescent version of the UCLA PTSD Reaction Index again and assessed thoroughly for PTSD symptoms (Fig. 1).

All the surveys were conducted through face-to-face interviews by trained psychiatrists, psychologists, psychiatric nurses, and social workers. All participants and their parents or guardians provided informed consent and were informed of their rights to withdraw at any time. During the interviews, the child was assessed in school without being accompanied by parents or guardians. This procedure ensured that all questions were completed by themselves without interruptions.

\section{Measures}

The adolescent version of the UCLA PTSD Reaction Index was used to evaluate symptoms of PTSD [40]. The index contains 20 items on a 5-point scale and is used to rate the frequency of symptom occurrence. It was translated into straightforward Chinese to assess children's 


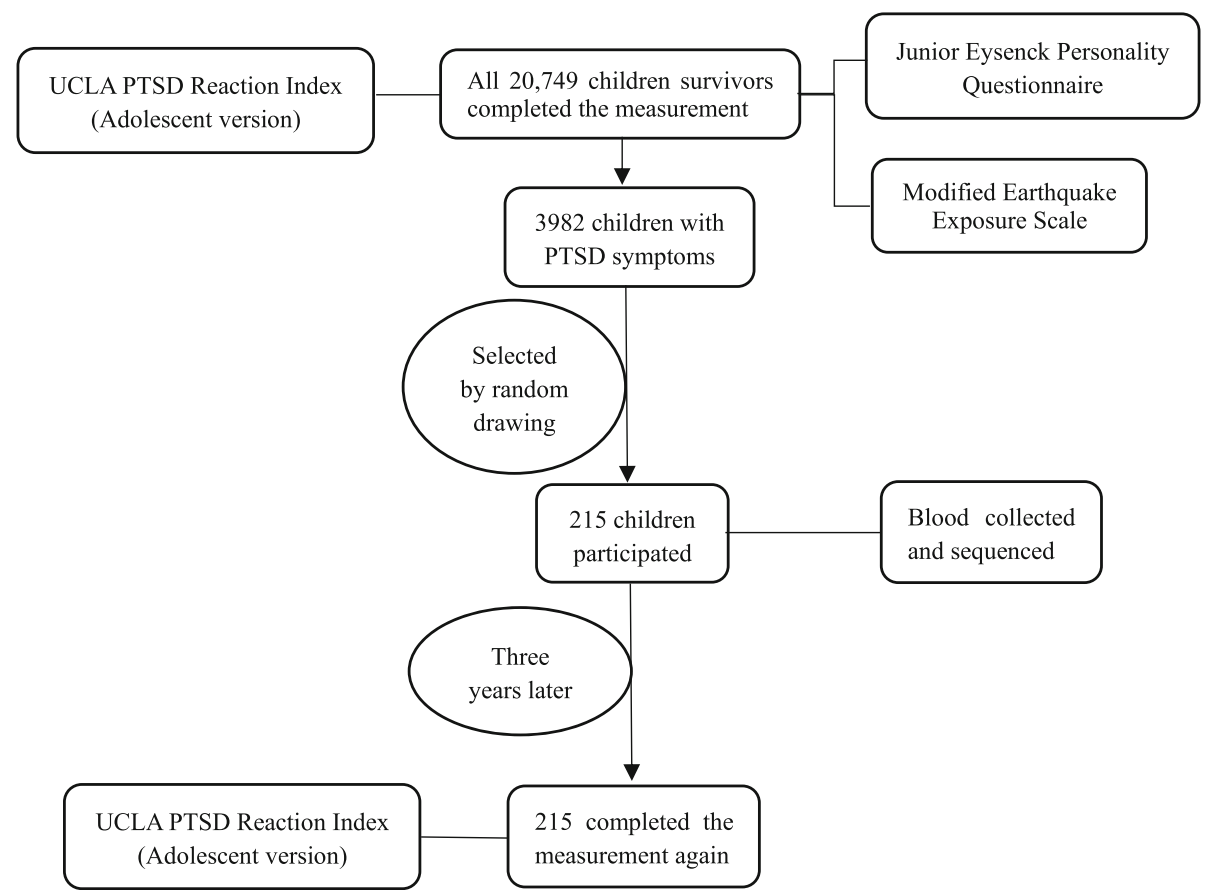

Fig. 1 Sampling stages for child survivors in Qingchuan, Sichuan Province, following the Wenchuan earthquake

symptoms. The index could evaluate almost all the signs of PTSD, including re-experiencing, avoidance, increased arousal symptoms, numbness, and pessimism symptoms [41]. If the total score is equal to or higher than 36, the child is identified as having symptoms of PTSD [42].

The earthquake exposure scale is an earthquakemodified version of the PsySTART Rapid Triage System [22]. It includes ten yes-and-no questions through which the results are more natural to obtain. The questions were adapted from the prior earthquake exposure scales, which were drafted based on the Diagnostic and Statistical Manual of Mental Disorders A-1 and A-2 criteria for PTSD $[43,44]$. The experiences could be separated into two categories. Half of the items are used to evaluate subjective factors, including having experienced extreme panic or fear and having felt others' or a family member's life to be in danger, while the others are used for objective factors, including the loss of a close family member or friend.

The Junior Eysenck Personality Questionnaire is a commonly used self-report questionnaire that was translated into Chinese and modified 30 years ago [45-48]. It is widely used in children aged 7 to 15 to assess their personality traits. The Chinese version of the JEPQ could evaluate four characteristics by 88 yes-or-no items. The four subscales are psychoticism (P), extraversion $(\mathrm{E})$, neuroticism $(\mathrm{N})$, and lie, with five levels in each. For example, the $\mathrm{P}$ subscale is divided into five levels: psychoticism $(\mathrm{T}<38.5)$, moderate psychoticism $(38.5 \leq \mathrm{T}<43.3)$, intermediate $(43.3 \leq \mathrm{T} \leq 56.7)$, moderate socialization $(56.7<\mathrm{T} \leq 61.5)$ and socialization $(\mathrm{T}>61.5)$. The other subscales are divided similarly.

\section{SNP selection and genotyping}

There is some evidence that PTSD may be related to LTP [49]. According to the literature search, candidate genes include AKT1, APP, BDNF, TrkB, NTF3, BMP, G72, CNTF, S100B, NGF, EGF, and PSEN2, and all of them participate in regulating LTP via NMDAR. We searched known SNPs from databases (NCBI and HapMap) and genotyped ten DNA samples from each group. Genomic DNA was extracted from whole blood samples using a TIANamp Blood DNA Kit (DP318-03, TIAN GEN, Beijing), and SNPs were genotyped with the SEQUENOM MassARRAYiPLEX platform. The assay consists of an initial locus-specific PCR, followed by single-base extension and matrix-assisted laser desorption/ionization-time of flight mass spectrometry to identify the SNP allele. Using Wang's method [50] and analyzing twenty DNA samples, 28 SNPs were selected with allele frequencies higher than $5 \%$. Finally, all blood samples were genotyped on 28 SNPs.

\section{Statistical analyses}

Statistical analyses were performed by $\mathrm{R}$, and packages of psych, MASS, AER, and leaps were used. The frequencies of all variables were calculated. The age and the scores of the adolescent version of the UCLA PTSD Reaction Index were described by the mean and standard deviation, and 
the others were described by counts and ratios. The chisquare test, Student's t-test, and the Wilcoxon rank-sum test were used to analyze the difference between the two groups. Furthermore, logistic regression analysis was used to adjust the influence of demographic factors and the severity of symptoms, and multinomial logistic regression analysis was used to identify the role of trauma experiences, personality traits, and genes. All factors were chosen in multinomial logistics regression, including the demographic data (sex, age, residence, removal or not), the scores of three scales, and all the results of the SNP test. R automatically searched for the model with the highest $R^{2}$, and the factors were selected by the software. The new multinomial logistic regression model had the factors chosen by the software, and this procedure yielded odds ratios with 95\% confidence intervals for each variable. Finally, $\mathrm{R}$ calculated the relative importance of predictor variables. All tests were two-tailed, and those that had $p$-values of 0.05 or lower were treated as statistically significant in all data analyses.

\section{Results}

\section{Demographic and clinical characteristics}

The demographic information and clinical characteristics of all 215 participants in this study are summarized in Table 1. The children were divided into two groups. One group consisted of children who did not recover from PTSD 3 years after the earthquake, while the children in the other group did. Compared with the children who did not recover from PTSD symptoms, the recovered group tended to be younger $(p<0.05)$, have lower avoidance scores $(\mathrm{p}<0.05)$ and have lower total UCLA-PTSD RI scores $(p<0.01)$.

For earthquake experience, the ratio of having trapped for a longer period of time was 49.7 and $13.3 \%$ for the nonrecovered and the recovered groups, respectively. The rates of feeling unable to escape from the disaster and having lost a close family member or friend were significantly different between the two groups.

With respect to the JEPQ, two groups showed significant differences on the E subscale $(p<0.001)$ and the $\mathrm{N}$ subscale $(\mathrm{p}<0.001)$, and the recovered group scored higher on the $\mathrm{E}$ subscale and lower on the $\mathrm{N}$ subscale.

Taking the demographic factors and the UCLA-PTSD RI as the covariance, there was a significant difference between the two groups on earthquake exposure and the JEPQ. The result of the logistic regression analysis showed that the recovered group had a greater feeling that one's own or a family member's life was in danger $(p<0.05)$, but the other results were similar to those of prior studies.

\section{Distribution of genotypes}

In the case of SNPs related to LTP, the results are presented in Table 2 . We found that they were basically the same in the two groups, and the $p$-values were $0.067-$ 0.916. After adjustments were made for the influence of demographic factors and the severity of symptoms, the results showed that TrkB (rs920776) was significantly different between the two groups $(p<0.05)$.

\section{Maintaining factors of PTSD symptoms}

The best regression model with the highest $R^{2}$ was made with eight variables, including being trapped for a longer period of time, feeling one's own or a family member's life to be in danger, Esubscales, Nsubscales, and SNPs (rs3916966, rs3918341, rs2515362) (Fig. 2 and Table 3). Protective factors are A5, Esubscales, and rs3916966, indicating that the child felt his own or a family member's life to be in danger, typically characterized by extraversion or with AA on rs3916966 seeming to recover from PTSD symptoms more quickly. Age, A4, Nsubscales, rs3918341, and rs2515362 were found to be risk factors indicating being an older child, being trapped for a longer period of time, being typically characterized by neuroticism, and having AA on rs3918341 and rs2515362 suffering more prolonged symptoms. Among multiple factors, the relative importance of predictor variables was calculated. The results showed that personality traits and traumatic experiences have the most significant influence on the maintenance of PTSD symptoms among child survivors of the Wenchuan earthquake (Fig. 3).

\section{Discussion}

This study was conducted among participants who underwent a natural, destructive disaster in a developing country. Due to the harsh natural environment, poor traffic conditions, and unbalanced medical conditions, these affected children went through a series of naturally developing processes of recovery from the post-earthquake stress reaction. That study explored the natural restoration processes of PTSD without treatment and found that demographic data, trauma experiences, personality traits, and genotype have a vital influence on the maintenance of PTSD symptoms.

There is some evidence to suggest the effect of age on PTSD symptoms. For example, a meta-analysis of 53 studies conducted by Tang found that older age was a significant predictor of children's PTSD [51]. We held the same views. This finding may be explained by changes in resilience, but further studies are needed to confirm this hypothesis [52]. Regarding gender, a correlation was found between female gender and a higher risk of PTSD [37, 53-57]. In contrast, there was no significant relationship between gender and the maintenance of symptoms. According to research purposes, the effect of demographic factors and the severity of symptoms were eliminated in the following analysis.

The experience of trauma, which has a significant impact on the initiation and development of PTSD, could be divided into two groups: A) objective experiences, including actual reality and losing a family member, and 
Table 1 Demographic and clinical characteristics of the participants

\begin{tabular}{|c|c|c|c|c|}
\hline & Nonrecovered $(\boldsymbol{N}=155)$ & Recovered $(\boldsymbol{N}=60)$ & $p$ & Adjusted $\mathrm{p}$ \\
\hline \multicolumn{5}{|l|}{ Demographic factors } \\
\hline Boys & $88(56.8 \%)$ & $30(50 \%)$ & 0.458 & - \\
\hline Age & $10.58 \pm 1.52$ & $10.08 \pm 1.52$ & 0.034 & - \\
\hline Residence: Town & $3(1.9 \%)$ & $3(5.0 \%)$ & 0.446 & - \\
\hline Move to another area after earthquake & $60(38.7 \%)$ & $19(31.7 \%)$ & 0.422 & - \\
\hline \multicolumn{5}{|l|}{ Earthquake exposure } \\
\hline Saw anyone dead or injured (A2) & $120(77.4 \%)$ & $42(70.0 \%)$ & 0.339 & 0.711 \\
\hline Felt others' panic (A3) & $137(88.4 \%)$ & $55(91.7 \%)$ & 0.651 & 0.100 \\
\hline Trapped for a longer period of time (A4) & 77 (49.7\%) & $8(13.3 \%)$ & $<0.001$ & $<0.001$ \\
\hline Felt one's own or a family member's life to be in danger (A5) & $128(82.6 \%)$ & $56(93.3 \%)$ & 0.072 & 0.039 \\
\hline Felt unable to escape from the disaster (A6) & $114(73.5 \%)$ & $34(56.7 \%)$ & 0.026 & 0.061 \\
\hline Felt extreme panic or fear (A7) & $144(92.9 \%)$ & $53(88.3 \%)$ & 0.418 & 0.460 \\
\hline Lost a close family member or friend (A8) & $55(35.5 \%)$ & $10(16.7 \%)$ & 0.011 & 0.013 \\
\hline Had a close family member or friend injured (A9) & $85(54.8 \%)$ & $34(56.7 \%)$ & 0.929 & 0.624 \\
\hline Lost home or important belongings (A10) & $126(81.3 \%)$ & $46(76.7 \%)$ & 0.569 & 0.520 \\
\hline Injured (A11) & $27(17.4 \%)$ & $6(10.0 \%)$ & 0.253 & 0.216 \\
\hline \multicolumn{5}{|l|}{ JEPQ } \\
\hline Psubscales & & & 0.577 & 0.355 \\
\hline Psychoticism & $25(16.1 \%)$ & $6(10.0 \%)$ & & \\
\hline Moderate psychoticism & $12(7.7 \%)$ & $8(13.3 \%)$ & & \\
\hline Intermediate & $73(47.1 \%)$ & $27(45.0 \%)$ & & \\
\hline Moderate socialization & $35(22.6 \%)$ & $13(21.7 \%)$ & & \\
\hline Socialization & $10(6.5 \%)$ & $6(10.0 \%)$ & & \\
\hline Esubscales & & & $<0.001$ & $<0.001$ \\
\hline Extraversion & $13(8.4 \%)$ & $14(23.3 \%)$ & & \\
\hline Moderate extraversion & $18(11.6 \%)$ & $16(26.7 \%)$ & & \\
\hline Intermediate & $76(49.0 \%)$ & $22(36.7 \%)$ & & \\
\hline Moderate introversion & $21(13.5 \%)$ & $6(10.0 \%)$ & & \\
\hline Introversion & 27 (17.4\%) & $2(3.3 \%)$ & & \\
\hline Nsubscales & & & $<0.001$ & $<0.001$ \\
\hline Neuroticism & $22(14.2 \%)$ & $2(3.3 \%)$ & & \\
\hline Moderate neuroticism & $31(20.0 \%)$ & $6(10.0 \%)$ & & \\
\hline Intermediate & 79 (51.0\%) & $23(38.3 \%)$ & & \\
\hline Moderate stability & $9(5.8 \%)$ & $11(18.3 \%)$ & & \\
\hline Stability & $14(9.0 \%)$ & $18(30.0 \%)$ & & \\
\hline \multicolumn{5}{|l|}{ UCLA-PTSD RI } \\
\hline Re-experiencing & $12.16 \pm 2.61$ & $11.80 \pm 2.40$ & 0.336 & - \\
\hline Avoidance & $17.12 \pm 3.41$ & $16.02 \pm 2.83$ & 0.017 & - \\
\hline Increased arousal & $13.66 \pm 3.06$ & $13.32 \pm 2.31$ & 0.378 & - \\
\hline Total score & $42.94 \pm 5.63$ & $41.13 \pm 3.84$ & 0.008 & - \\
\hline
\end{tabular}

B) subjective experiences, including personal feelings, intense fear, helplessness, or horror [58, 59]. There was some evidence to suggest that both subjective and objective earthquake exposure experiences could influence the development of PTSD symptoms [20, 60, 61]. On the other hand, we further confirmed their effects on maintenance symptoms and found that one subjective experience, namely, feeling one's own or a family 
Table 2 The distribution of genotypes of all SNPs: a) 0 represents the common homozygotes; b) 1 represents the heterozygotes; and c) 2 represents rare homozygotes

\begin{tabular}{|c|c|c|c|c|c|c|c|c|c|c|}
\hline \multirow[t]{2}{*}{ Gene } & \multirow[t]{2}{*}{ SNP ID symbol } & \multicolumn{3}{|c|}{ Nonrecovered $(N=155)$} & \multicolumn{3}{|c|}{ Recovered $(\mathrm{N}=60)$} & \multirow[t]{2}{*}{$x^{2}$} & \multirow[t]{2}{*}{$P^{*}$} & \multirow[t]{2}{*}{$p^{* *}$} \\
\hline & & $\overline{0^{a}}$ & $1^{\mathrm{b}}$ & $2^{c}$ & $\overline{0}$ & 1 & 2 & & & \\
\hline \multirow[t]{3}{*}{ PS2 } & rs1046240 & $60(38.7)$ & $78(50.3)$ & $17(11.0)$ & $26(43.3)$ & $26(43.3)$ & $8(13.3)$ & 0.876 & 0.645 & 0.555 \\
\hline & rs1295645 & $9(5.8)$ & $57(36.8)$ & 89 (57.4) & $2(3.3)$ & $18(30.0)$ & $40(66.7)$ & 1.703 & 0.427 & 0.182 \\
\hline & rs8383 & $16(10.3)$ & $83(53.5)$ & $56(36.1)$ & $8(13.3)$ & $26(43.3)$ & $26(43.3)$ & 1.830 & 0.401 & 0.456 \\
\hline NOS1 & rs1047735 & $42(27.1)$ & $77(49.7)$ & $36(23.2)$ & $14(23.3)$ & $39(65.0)$ & $7(11.7)$ & 5.007 & 0.082 & 0.382 \\
\hline \multirow[t]{5}{*}{ TrkB } & rs1047896 & 127 (81.9) & $28(18.1)$ & $0(0.0)$ & $44(73.3)$ & $15(25.0)$ & $1(1.7)$ & 4.026 & 0.134 & 0.140 \\
\hline & rs1624327 & $3(1.9)$ & $46(29.7)$ & $106(68.4)$ & $2(3.3)$ & 19 (31.7) & $39(65.0)$ & 0.494 & 0.781 & 0.748 \\
\hline & rs2013566 & $5(3.2)$ & $53(34.2)$ & 97 (62.6) & $2(3.3)$ & $14(23.3)$ & $44(73.3)$ & 2.401 & 0.301 & 0.171 \\
\hline & rs7020204 & $4(2.6)$ & $53(34.2)$ & $98(63.2)$ & $2(3.3)$ & $15(25.0)$ & $43(71.7)$ & 1.714 & 0.425 & 0.323 \\
\hline & rs920776 & $5(3.2)$ & $57(36.8)$ & $93(60.0)$ & $1(1.7)$ & $13(21.7)$ & $46(76.7)$ & 5.268 & 0.072 & 0.025 \\
\hline AKT1 & rs1130233 & $27(17.4)$ & $70(45.2)$ & $58(37.4)$ & $7(11.7)$ & $33(55.0)$ & $20(33.3)$ & 1.978 & 0.372 & 0.729 \\
\hline \multirow[t]{8}{*}{ G72 } & rs2391191 & $45(29.0)$ & $84(54.2)$ & $26(16.8)$ & $18(30.0)$ & $30(50.0)$ & $12(20.0)$ & 0.412 & 0.814 & 0.647 \\
\hline & rs1421292 & $53(34.2)$ & $80(51.6)$ & $22(14.2)$ & $23(38.3)$ & $30(50.0)$ & $7(11.7)$ & 0.426 & 0.804 & 0.615 \\
\hline & rs3916965 & $26(16.8)$ & $83(53.5)$ & $46(29.7)$ & $12(20.0)$ & $30(50.0)$ & $18(30.0)$ & 0.360 & 0.835 & 0.617 \\
\hline & rs3916966 & $46(29.7)$ & $83(53.5)$ & $26(16.8)$ & $18(30.0)$ & $30(50.0)$ & $12(20.0)$ & 0.360 & 0.835 & 0.596 \\
\hline & rs3918341 & $42(27.1)$ & $85(54.8)$ & $28(18.1)$ & $20(33.3)$ & $28(46.7)$ & $12(20.0)$ & 1.220 & 0.543 & 0.872 \\
\hline & rs3918342 & 32 (20.6) & $87(56.1)$ & $36(23.2)$ & $11(18.3)$ & $34(56.7)$ & $15(25.0)$ & 0.175 & 0.916 & 0.880 \\
\hline & rs778294 & $107(69.0)$ & $41(26.5)$ & $7(4.5)$ & $42(70.0)$ & $18(30.0)$ & $0(0.0)$ & 2.914 & 0.233 & 0.464 \\
\hline & rs947267 & $28(18.2)$ & $77(50.0)$ & 49 (31.8) & $8(13.3)$ & $33(55.0)$ & 19 (31.7) & 0.814 & 0.666 & 0.645 \\
\hline S100B & rs2300403 & $43(27.7)$ & $82(52.9)$ & 30 (19.4) & $18(30.0)$ & $28(46.7)$ & $14(23.3)$ & 0.741 & 0.690 & 0.856 \\
\hline CNTF & rs2515362 & $12(7.7)$ & $71(45.8)$ & $72(46.5)$ & 11 (18.3) & $25(41.7)$ & $24(40.0)$ & 5.105 & 0.078 & 0.070 \\
\hline APP & rs2830102 & $5(3.2)$ & $56(36.1)$ & $94(60.6)$ & $4(6.7)$ & $19(31.7)$ & $37(61.7)$ & 1.478 & 0.478 & 0.639 \\
\hline \multirow[t]{3}{*}{ DISC1 } & rs4658971 & $7(4.5)$ & $56(36.1)$ & $92(59.4)$ & $2(3.3)$ & $24(40.0)$ & $34(56.7)$ & 0.372 & 0.830 & 0.731 \\
\hline & rs821597 & 30 (19.4) & $82(52.9)$ & $43(27.7)$ & $13(21.7)$ & $28(46.7)$ & $19(1.7)$ & 0.675 & 0.713 & 0.976 \\
\hline & rs821616 & $122(78.7)$ & $28(18.1)$ & $5(3.2)$ & $50(83.3)$ & $8(13.3)$ & $2(3.3)$ & 0.695 & 0.706 & 0.510 \\
\hline BDNF & rs6265 & $46(29.7)$ & $73(47.1)$ & $36(23.2)$ & $15(25.0)$ & $31(51.7)$ & $14(23.3)$ & 0.521 & 0.771 & 0.630 \\
\hline NGF & rs6330 & $5(3.2)$ & $47(30.3)$ & 103 (66.6) & $1(1.7)$ & $26(43.3)$ & $33(55.0)$ & 3.430 & 0.180 & 0.066 \\
\hline NTF3 & rs6332 & $37(23.9)$ & $83(53.5)$ & 35 (22.6) & $18(30.0)$ & $30(50.0)$ & $12(20.0)$ & 0.871 & 0.647 & 0.489 \\
\hline PS1 & rs7523 & $106(68.4)$ & $40(25.8)$ & $9(5.8)$ & $38(63.3)$ & $22(36.7)$ & $0(0.0)$ & 5.418 & 0.067 & 0.635 \\
\hline
\end{tabular}

member's life to be in danger, was a protective factor, and two objective experiences, namely, being trapped for a longer period of time and having lost a close family member or friend, were risk factors for the maintenance of PTSD symptoms. This inconsistency may be due to the differences in duration. Subjective exposure did not always represent objective reality, and measures such as spending time with others would help children feel safe with the dissipation of their undesirable feelings. By contrast, PTSD symptoms caused by objective exposure could last longer and require more attention.

Personality traits are conceptualized as dimensions of individual differences in tendencies to show consistent patterns of thoughts, feelings, and contexts [62]. Numerous models are used to describe personality traits, the most common of which are neuroticism, extraversion, and psychoticism. There were several differences in personality traits between the recovered and nonrecovered groups, such as neuroticism and extraversion. The findings of this study showed that neuroticism tends to be a risk factor with all elements under consideration. In the same way, the evidence from previous studies suggested that an increased level of neuroticism indicates a higher risk of developing PTSD and could be used as a critical predictor [23, 63, 64]. This phenomenon may result from the character of neuroticism. For example, one with a stronger trait of neuroticism often seems moody and excitable, and after a series of mishaps, children with unstable emotions usually develop psychiatric symptoms more easily and have a harder time recovering. Extraversion can be defined as positive emotional aspects interpersonally and socially and is generally seen as a factor strongly related to numerous psychological 


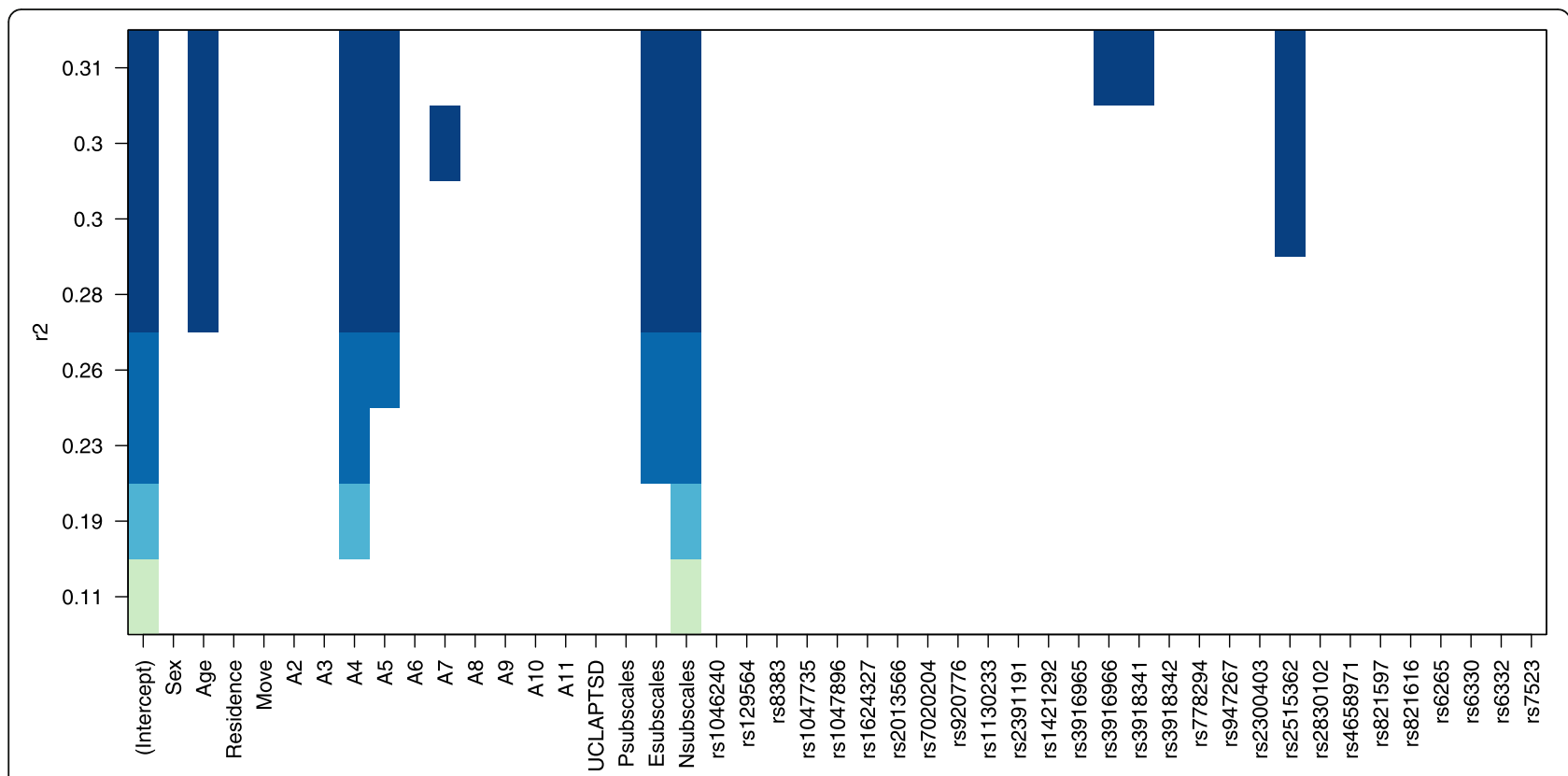

Fig. 2 Plot for all subset regressions

illnesses [65]. In their useful study, Nenad found that PTSD symptoms were negatively associated with extraversion [66]. Likewise, extraversion helped to alleviate PTSD symptoms in our results. There are several possible explanations for this result. Children with a higher trait of extraversion tend to be high in gregariousness, activity, and enthusiasm [67]. They are usually more able to relieve their emotions and find social support, which means that they can alleviate PTSD symptoms as soon as possible.

Another significant aspect of the effect factor is hereditary. This study focused on LTP, which is induced in a variety of brain regions with diverse simulation protocols and requires activation by NMDARs. NMDARs are vital mediators of excitatory synaptic transmission and are adjusted by numerous factors, such as TrkB, G72, and CNTF $[68,69]$. The evidence from this study showed that TrkB (rs920776) was differentially distributed between the recovered group

Table 3 Logistic regression analysis of the factors selected by all-subset regression

\begin{tabular}{llll}
\hline & OR & $p$ & $95 \% \mathrm{Cl}$ \\
\hline Age & 0.756 & 0.021 & $0.593,0.957$ \\
A4 & 0.166 & $<0.001$ & $0.061,0.398$ \\
A5 & 6.023 & 0.006 & $1.836,24.776$ \\
Esubscales & 1.865 & 0.001 & $1.304,2.760$ \\
Nsubscales & 0.469 & $<0.001$ & $0.319,0.667$ \\
Rs3916966 & 12.706 & 0.048 & $1.458,310.089$ \\
Rs3918341 & 0.088 & 0.055 & $0.004,0.734$ \\
Rs2515362 & 0.509 & 0.020 & $0.283,0.890$ \\
\hline
\end{tabular}

and the nonrecovered group within 3 years. TrkB is a single transmembrane receptor of BDNF and is essential for the formation of memories [70]. The BDNF pathway was assumed to play a role in several psychiatric disorders, including PTSD [71]. There is some evidence to suggest that enhanced levels of TrkB during fear memory consolidation are associated with long-lasting fear memory [72]. Moreover, recent research has revealed that BDNF-TrkB is a protective factor against PTSD. For example, a decrease in its signaling is likely a contributing factor in PTSD [73, 74], and BDNF-TrkB signaling might be a novel therapeutic strategy for impaired fear memory extinction by stress [75]. Previous studies have suggested a relationship between TrkB and PTSD, and we further strengthened this relationship. We found that TrkB is a contributory factor to the maintenance of PTSD, which could be caused by its participation in support of impaired contextual fear learning and fear extinction [73]. In addition, after other factors were excluded, G72 (rs3916966, rs3918341) and CNTF (rs2515362) tended to be influencing factors. The G72 genes are located on chromosome 13q33 and encode a primate-specific protein named pLG72, which is known as an interacting partner of flavoenzyme D-amino acid oxidase that could degrade the key endogenous co-agonist of NMDAR [76-78]. Previous researchers found evidence of the association between G72 polymorphisms, including rs3918342 and rs3696165, and schizophrenia, bipolar disorder, and major depressive disorder [79-83]. However, the relationship between G72 and PTSD has yet to be reported. CNTF can influence several types of peripheral and central neurons [84, 85], reduce synaptic depression during 


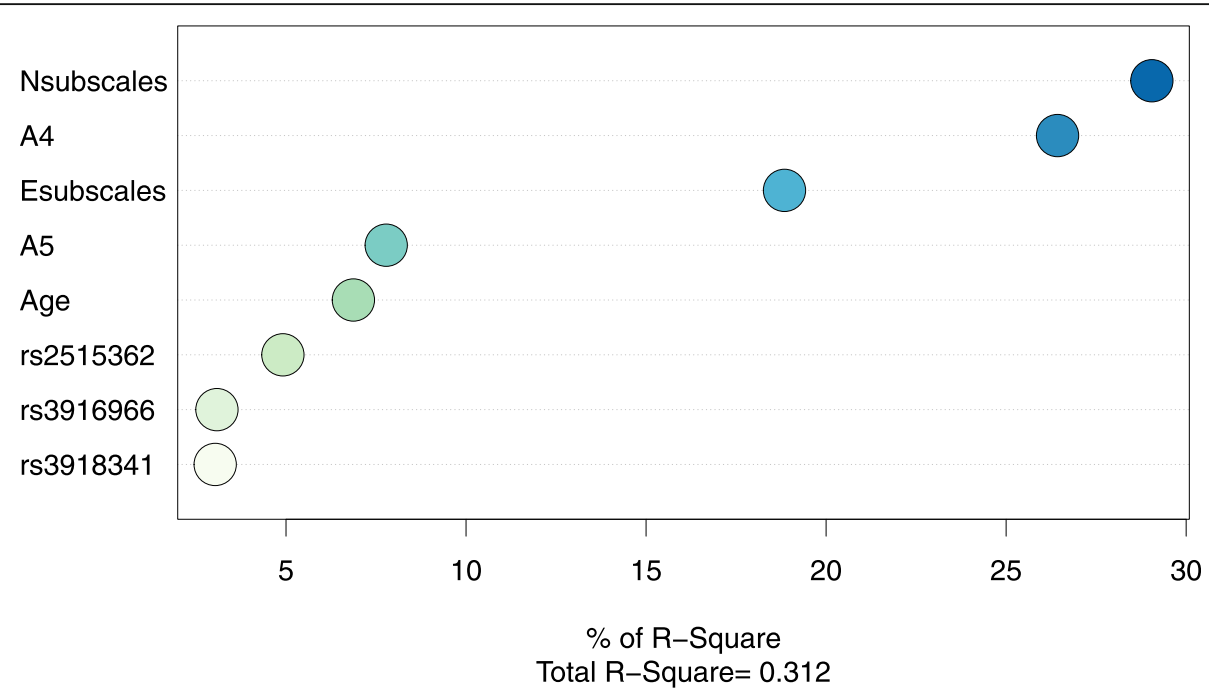

Fig. 3 Relative importance of predictor variables

repetitive stimulation [86] and protect neurons from hypoxic injury [87]. CNTF levels increased in major depressive disorder, and CNTF was seen as a factor related to mental disease [88]. In addition, CNTF influenced stress-induced cortical norepinephrine synthesis, ensuing neuronal excitation and behavioral stereotypes [89], which may build a bridge between trauma experience and PTSD.

It is worth noting that among all probable factors, including demographic factors, the severity of symptoms, personality traits, trauma experiences and genes, personality traits, exposure experiences, and age played the most crucial role in the maintenance of PTSD. On the other hand, the currently known related genes showed limited influence on the maintenance of PTSD. This result may be caused by the small impact of single SNPs or the mediation of gene expression. A single SNP will not be enough to influence PTSD, but it probably sets up the genomic precondition, while personality traits, experiences, and the subsequent environment lead in the same direction. The interaction between the environment and genotype should also be considered, and other genes should be included to build the formula of the prediction model. This approach will more clearly demonstrate the influence of genes.

This study had some limitations. First, since the participants were selected among survivors, the sample sizes of each group were unbalanced. Expanding the sample quantity may solve this problem. Second, this study followed up for 3 years, during which some of the participants recuperated. Follow-up of all patients until recovery would be more productive and informative. Third, this study measured the children's personality traits after the earthquake, which meant that their experiences and PTSD symptoms could influence their personality traits and PTSD symptoms. A longitudinal study for people who live in an area where seismic activities are higher may be more worthwhile. However, this means that the survey will risk higher costs and more uncertainty. Moreover, it is vital to check the interrater reliability between rater groups in epidemiological studies, especially those that use other-report questionnaires. However, in our research, the three scales that we used in the study were self-report questionnaires. Before the interviews, we provided written instructions to the interviewers, and their responses clarified the meaning of the question stem. Therefore, the interrater reliability between rater groups was not checked.

\section{Conclusions}

In summary, it has been shown from this study that experiences, personality traits, and genotype influenced the maintenance of PTSD in child survivors who were considered to be followed up without medicine. Postnatal factors are more impactful, whereas LTP genes, such as TrkB, G72, and CNTF, also play essential roles. With the inclination of limited medical resources, targeted measures for specific child survivors could lead to more benefits. In clinical practice, older children with a high tendency toward neuroticism and objective trauma experience a longer duration of symptoms, and they should receive more attention and medical assistance. Individualized psychotherapy aimed directly at personality traits may increase the rate of recovery. The previous section has shown the possible reasons for TrkB, G72, and CNTF in the maintenance of PTSD. Despite providing an equivocal explanation for the relationship and possible reasons, this result anticipates stimulating inspiration for the exploration of directions and research emphases. 


\section{Abbreviations}

PTSD: Posttraumatic stress disorder; LTP: Long-term potentiation; NMDA Rs: NMDA receptors; JEPQ: Junior Eysenck Personality Questionnaire; P: Psychoticism; E: Extraversion; N: Neuroticism

\section{Acknowledgments}

The authors are grateful to Professor S Chen and Professor M.Y Qian for their authorization of scales. Also, we express thanks to $X$ Zhao for assistance with data collection.

\section{Authors' contributions}

Y.L, analyzed and interpreted the patient data, drafted the manuscript. Q.L, study design and collect data. B.L, study design and collect data. D.L, study design and collect data. X.S, correct errors and provide important intellectual content. J.X, study design and administration, and final approval of publication. All authors read and approved the final manuscript.

\section{Funding}

This work was supported by the National Natural Science Foundation of China (Grant No. 81401132) and the Sichuan Science and Technology Support Program (Grant No. 2019YFS0218). The recipient of these programs is Jiajun Xu. He worked on study design and administration, and final approval of publication. The funding bodies had no role in the design of the study and collection, analysis, and interpretation of data and in writing the manuscript.

\section{Availability of data and materials}

The datasets used and analyzed during the current study are available from the corresponding author on reasonable request.

\section{Ethics approval and consent to participate}

The study protocol was reviewed and approved by the Sichuan University's Ethical and confidentiality committee. All procedures were conducted in accordance with the approved guidelines. All participants and their parents or guardians provided written informed consent in the study.

\section{Consent for publication}

\author{
Not applicable.
}

\section{Competing interests}

The authors declare that they have no competing interests.

\section{Received: 7 April 2020 Accepted: 30 August 2020}

\section{Published online: 07 September 2020}

\section{References}

1. McLaughlin KA, Berglund P, Gruber MJ, Kessler RC, Sampson NA, Zaslavsky AM. Recovery from PTSD following hurricane Katrina. Depress Anxiety. 2011; 28(6):439-46.

2. Cougle JR, Heidi R, Kilpatrick DG. PTSD, depression, and their comorbidity in relation to suicidality: cross-sectional and prospective analyses of a national probability sample of women. Depress Anxiety. 2010;26(12):1151-7.

3. Jia Z, Tian W, He X, Liu W, Jin C, Ding H. Mental health and quality of life survey among child survivors of the 2008 Sichuan earthquake. Qual Life Res. 2010;19(9):1381-91.

4. Chen XC, Xu JJ, Li B, Li N, Guo WJ, Ran MS, Zhang J, Yang YC, Hu JM. The role of personality and subjective exposure experiences in posttraumatic stress disorder and depression symptoms among children following Wenchuan earthquake. Sci Rep. 2017;7(1):17223.

5. Wang W, Fu W, Wu J, Ma XC, Sun XL, Huang Y, Hashimoto K, Gao CG. Prevalence of PTSD and depression among junior middle school students in a rural town far from the epicenter of the Wenchuan earthquake in China. PLoS One. 2012;7(7):e41665.

6. De Bellis MD, Zisk A. The biological effects of childhood trauma. Child Adolesc Psychiatr Clin N Am. 2014;23(2):185-222 vii.

7. Ehlers A, Bisson JClark DM, Creamer M, Pilling S, Richards D, Schnurr PP, Turner $S$, Yule W. Do all psychological treatments really work the same in posttraumatic stress disorder? Clin Psychol Rev. 2010;30(2):269-76.

8. Weisz JR, Jensen AL. Child and adolescent psychotherapy in research and practice contexts: review of the evidence and suggestions for improving the field. Eur Child Adolesc Psychiatry. 2001;10(Suppl 1):112-8.
9. Stein DJ, Ipser J, McAnda N. Pharmacotherapy of posttraumatic stress disorder: a review of meta-analyses and treatment guidelines. CNS Spectr. 2009;14(1 Suppl 1):25-31.

10. Fazel M. Who seeks treatment after a traumatic event and who does not? A review of findings on mental health service utilization. J Trauma Stress. 2010;18(6):595-605.

11. Morina N, Rushiti F, Salihu M, Ford JD. Psychopathology and well-being in civilian survivors of war seeking treatment: a follow-up study. Clin Psychol Psychother. 2010;17(2):79-86.

12. Usami M, Iwadare Y, Watanabe K, Kodaira M, Ushijima H, Tanaka T, Harada M, Tanaka H, Sasaki Y, Saito K. Decrease in the traumatic symptoms observed in child survivors within three years of the 2011 Japan earthquake and tsunami. PLoS One. 2014;9(10):e110898.

13. Dyb G, Jensen TK, Nygaard E. Children's and parents' posttraumatic stress reactions after the 2004 tsunami. Clin Child Psychol Psychiatry. 2011;16(4): $621-34$

14. Iwadare Y, Usami M, Suzuki Y, Ushijima H, Tanaka T, Watanabe K, Kodaira M, Saito K. Posttraumatic symptoms in elementary and junior high school children after the 2011 Japan earthquake and tsunami: symptom severity and recovery vary by age and sex. J Pediatr. 2014;164(4):917-21 e911.

15. Hafstad GS, Kilmer RP, Gil-Rivas V. Posttraumatic growth among Norwegian children and adolescents exposed to the 2004 tsunami. Psychol Trauma-Us. 2011;3(2):130-8.

16. Mullett-Hume E, Anshel D, Guevara V, Cloitre M. Cumulative trauma and posttraumatic stress disorder among children exposed to the 9/11 world trade center attack. Am J Orthopsychiatry. 2010;78(1):103-8.

17. Hong C, Efferth T. Systematic review on post-traumatic stress disorder among survivors of the Wenchuan earthquake. Trauma Violence Abuse. 2016;17(5):542-61.

18. Zhou X, Song H, Hu M, Li X, Cai Y, Huang G, Li J, Kang L, Li J. Risk factors of severity of post-traumatic stress disorder among survivors with physical disabilities one year after the Wenchuan earthquake. Psychiatry Res. 2015; 228(3):468-74.

19. Matsumoto K, Sakuma A, Ueda I, Nagao A, Takahashi Y. Psychological trauma after the great East Japan earthquake. Psychiatry Clin Neurosci. 2016; 70(8):318-31.

20. Roussos A, Goenjian AK, Steinberg AM, Sotiropoulou C, Kakaki M, Kabakos C, Karagianni S, Manouras V. Posttraumatic stress and depressive reactions among children and adolescents after the 1999 earthquake in Ano Liosia, Greece. Am J Psychiatry. 2005;162(3):530-7.

21. Vernberg EM, Silverman WK, La Greca AM, Prinstein MJ. Prediction of posttraumatic stress symptoms in children after hurricane Andrew. J Abnorm Psychol. 1996;105(2):237-48.

22. Thienkrua W, Cardozo BL, Chakkraband MLS, Guadamuz TE, Pengjuntr W, Tantipiwatanaskul P, Sakornsatian S, Ekassawin S, Panyayong B, Varangrat A, et al. Symptoms of posttraumatic stress disorder and depression among children in tsunami-affected areas in southern Thailand. JAMA. 2006;296(5): 549-59.

23. Fauerbach JA, Lawrence JW, Schmidt CW Jr, Munster AM, Costa PT Jr. Personality predictors of injury-related posttraumatic stress disorder. J Nerv Ment Dis. 2000;188(8):510-7.

24. Gil S. Pre-traumatic personality as a predictor of post-traumatic stress disorder among undergraduate students exposed to a terrorist attack: a prospective study in Israel. Pers Indiv Differ. 2005;39(4):819-27.

25. Wolf EJ, Miller MW, Harrington KM, Reardon A. Personality-based latent classes of posttraumatic psychopathology: personality disorders and the internalizing/externalizing model. J Abnorm Psychol. 2012;121(1):256-62.

26. Baltaci SB, Mogulkoc R, Baltaci AK. Molecular mechanisms of early and late LTP. Neurochem Res. 2019:44(2):281-96.

27. Kruijssen DLH, Wierenga CJ. Single Synapse LTP: A Matter of Context? Front Cell Neurosci. 2019:13(496):1-16.

28. Kolb B, Harker A, Gibb R. Principles of plasticity in the developing brain. Dev Med Child Neurol. 2017;59(12):1218-23.

29. Pereda-Pérez I, Popović N, BBo O, Popović M, Madrid JA, Rol MA, Venero C. Long-term social isolation in the adulthood results in CA1 shrinkage and cognitive impairment. Neurobiol Learn Memory. 2013;106(Complete):31-9.

30. Kehoe P, Bronzino JD. Neonatal stress alters LTP in freely moving male and female rats. Hippocampus. 1999:9(6):651-8.

31. Wei MD, Wang YH, Lu K, Lv BJ, Wang Y, Chen WY. Ketamine reverses the impaired fear memory extinction and accompanied depressive-like behaviors in adolescent mice. Behav Brain Res. 2020;379:112342. 
32. He M, Wei JX, Mao M, Zhao GY, Tang JJ, Feng S, Lu XM, Wang YT. Synaptic plasticity in PTSD and associated comorbidities: the function and mechanism for diagnostics and therapy. Curr Pharm Des. 2018;24(34):4051-9.

33. Pláteník J, Kuramoto N, Yoneda Y. Molecular mechanisms associated with long-term consolidation of the NMDA signals. Life Sci. 2000;67(4):335-64.

34. Black IB. Trophic regulation of synaptic plasticity. J Neurobiol. 2015;41(1): $108-18$.

35. Mu JS, Li WP, Yao ZB, Zhou XF. Deprivation of endogenous brain-derived neurotrophic factor results in impairment of spatial learning and memory in adult rats. Brain Res. 1999;835(2):259-65.

36. Stone R. Sichuan disaster. Landslides, flooding pose threats as experts survey quake's impact. Science. 2008;320(5879):996-7.

37. Zhang W, Duan G, Xu Q, Jia Z, Bai Z, Liu W, Pan X, Tian W. A crosssectional study on posttraumatic stress disorder and general psychiatric morbidity among adult survivors 3 years after the Wenchuan earthquake, China. Asia Pac J Public Health. 2015;27(8):860-70.

38. Yule W, Bolton D, Udwin O, Boyle S, Nurrish J. The long-term psychological effects of a disaster experienced in adolescence: I: the incidence and course of PTSD. J Child Psychol Psychiatry Allied Discip. 2010;41(4):503-11.

39. Bolton D, O'Ryan D, Udwin O, Boyle S, Yule W. The long-term psychological effects of a disaster experienced in adolescence: II: general psychopathology. J Child Psychol Psychiatry. 2010;41(4):513-23.

40. Steinberg AM, Brymer MJ, Decker KB, Pynoos RS. The University of California at Los Angeles post-traumatic stress disorder reaction index. Curr Psychiatry Rep. 2004;6(2):96-100.

41. Sue-HueiChen Y-HL. Hsu-MinTseng, yin-ChangWu: posttraumatic stress reactions in children and adolescents one year after the 1999 Taiwan chichi earthquake. J Chin Inst Eng. 2002;25(5):597-608.

42. Zhang $\mathrm{H}$ : A followup study of child survivors of the 1999 Taiwan earthquake: posttraumatic stress reactions and school-based intervention. Taiwan: Chang Gung University; 2006.

43. Gurwitch RH, Michelle K, Becker SM, Merritt S, Betty P, Dickson D. When disaster strikes: responding to the needs of children. Prehospital Disaster Med. 2004;19(1):21-8.

44. Kaplan HI, Sadock BJ. Comprehensive textbook of psychiatry; 1995.

45. Gong Y. Eysenck personality questionnaire revised in China. Psychol Sci. 1984:4:11-17.

46. Chen ZG. Item analysis of EYSENCK personality questionnaire tested in Beijing-district. Acta Psychol Sin. 1983;15(02):85-92.

47. Gong YX. Use of the Eysenck personality questionnaire in China. Pers Indiv Differ. 1984;5(4):431-8.

48. Zhu C, Yang C, Ma Y, Liu X, Min Y. EYSENCK personality QUESTIONAIRE(junior) used in Chengdu. J Sichuan Univ. 1983:14(2):149-59.

49. Friedman MJ, Charney DS, Deutch AY. Neurobiological and clinical consequences of stress: from normal adaptation to post-traumatic stress disorder; 1995.

50. Wang Q, Tian F, Pan Y, Buckler ES, Zhang Z. A SUPER powerful method for genome wide association study. PLoS One. 2014;9(9):e107684.

51. Tang B, Deng Q, Glik D, Dong J, Zhang L: A Meta-Analysis of Risk Factors for Post-Traumatic Stress Disorder (PTSD) in Adults and Children after Earthquakes. Int J Environ Res Public Health. 2017; 14(12):1-20.

52. Horn SR, Charney DS, Feder A. Understanding resilience: New approaches for preventing and treating PTSD. Exp Neurol. 2016;284(Pt B):119-32.

53. Lambert JF, Difede J, Contrada RJ. The relationship of attribution of responsibility to acute stress disorder among hospitalized burn patients. J Nerv Ment Dis. 2004;192(4):304-12.

54. Maes M, Delmeire L, Mylle J, Altamura C. Risk and preventive factors of post-traumatic stress disorder (PTSD): alcohol consumption and intoxication prior to a traumatic event diminishes the relative risk to develop PTSD in response to that trauma. J Affect Disord. 2001;63(1-3): $113-21$.

55. Van Loey NE, Maas CJ, Faber AW, Taal LA. Predictors of chronic posttraumatic stress symptoms following burn injury: results of a longitudinal study. J Trauma Stress. 2003;16(4):361-9.

56. Mimmie W, Gerhard A, Lisa E. Prediction of psychological health after an accidental burn. J Trauma. 2004;57(2):367-74.

57. Lu MK, Lin YS, Chou P, Tung TH. Post-traumatic stress disorder after severe burn in southern Taiwan. Burns. 2007;33(5):649-52.

58. Perrin S, Smith P, Yule W. Practitioner review: the assessment and treatment of post-traumatic stress disorder in children and adolescents. J Child Psychol Psyc. 2000;41(3):277-89.
59. Trickey D, Siddaway AP, Meiser-Stedman R, Serpell L, Field AP. A metaanalysis of risk factors for post-traumatic stress disorder in children and adolescents. Clin Psychol Rev. 2012;32(2):122-38.

60. Roy L, Deborah R, Lea DF, Spencer E. Impact of trauma on children. J Psychiatr Pract. 2003;9(2):128-38.

61. Mcdermott BM, Palmer LJ. Postdisaster emotional distress, depression and event-related variables: findings across child and adolescent developmental stages. Aust New Zealand J Psychiatry. 2015;36(6):754-61.

62. Mccrae RR, Costa PT. Personality in adulthood: a five-factor theory perspective, 2nd ed. Int Cult Psychol. 2003;8:303-22.

63. Hobbs K. Which factors influence the development of post-traumatic stress disorder in patients with burn injuries? A systematic review of the literature. Burns. 2015:41(3):421-30.

64. Lawrence JW, Fauerbach JA. Personality, coping, chronic stress, social support and PTSD symptoms among adult burn survivors - a path analysis. J Burn Care Rehabil. 2003;24(1):63-72.

65. Spinhoven P, Elzinga BM, van Hemert AM, de Rooij M, Penninx BW. A longitudinal study of facets of extraversion in depression and social anxiety. Pers Indiv Differ. 2014;71(2):39-44.

66. Jaksic N, Brajkovic L, Ivezic E, Topic R, Jakovljevic M. The role of personality traits in posttraumatic stress disorder (Ptsd). Psychiat Danub. 2012;24(3):256-66.

67. Watson D, Clark LA. Extraversion and its positive emotional core; 1997.

68. Yashiro K, Philpot BD. Regulation of NMDA receptor subunit expression and its implications for LTD, LTP, and metaplasticity. Neuropharmacology. 2008; 55(7):1081-94

69. Bliss TV, Collingridge GL. Expression of NMDA receptor-dependent LTP in the hippocampus: bridging the divide. Mol Brain. 2013;6(1):5.

70. Andero R, Choi DC, Ressler KJ. Chapter six - BDNF-TrkB receptor regulation of distributed adult neural plasticity, memory formation, and psychiatric disorders. Progress Mol Biol Transl Sci. 2014;122:169-92.

71. Breslau N, Kessler RC, Chilcoat HD, Schultz LR, Davis GC, Andreski P. Trauma and posttraumatic stress disorder in the community: the 1996 Detroit area survey of trauma. Arch Gen Psychiatry. 1998;55(7):626-32.

72. Takei S, Morinobu S, Yamamoto S, Fuchikami M, Matsumoto T, Yamawaki S. Enhanced hippocampal BDNF/TrkB signaling in response to fear conditioning in an animal model of posttraumatic stress disorder. J Psychiatr Res. 2011:45(4):460-8.

73. Green CR, Corsi-Travali S, Neumeister A: The Role of BDNF-TrkB Signaling in the Pathogenesis of PTSD. J Depress Anxiety 2013, 2013(S4):1-13.

74. Sanz-Garcia A, Knafo S, Pereda-Perez I, Esteban JA, Venero C, Armario A. Administration of the TrkB receptor agonist 7,8-dihydroxyflavone prevents traumatic stress-induced spatial memory deficits and changes in synaptic plasticity. Hippocampus. 2016;26(9):1179-88.

75. Kataoka T, Fuchikami M, Nojima S, Nagashima N, Araki M, Omura J, Miyagi T, Okamoto Y, Morinobu S. Combined brain-derived neurotrophic factor with extinction training alleviate impaired fear extinction in an animal model of post-traumatic stress disorder. Genes Brain Behav. 2019;18(7):e12520.

76. Mothet JP, Parent AT, Wolosker H, Brady RO, Linden DJ, Ferris CD, Rogawski MA, Snyder SH. D-serine is an endogenous ligand for the glycine site of the N-methyl-D-aspartate receptor. Proc Natl Acad Sci U S A. 2000;97(9):492631.

77. Aude $\mathrm{P}$, Theodosis DT, Jean-Pierre M, Bastien T, Loredano P, Poulain DA, Oliet SHR. Glia-derived D-serine controls NMDA receptor activity and synaptic memory. Cell. 2006;125(4):775-84.

78. Papouin T, Ladepeche L, Ruel J, Sacchi S, Labasque M, Hanini M, Groc L, Pollegioni L, Mothet JP, Oliet SH. Synaptic and extrasynaptic NMDA receptors are gated by different endogenous coagonists. Cell. 2012;150(3): 633-46.

79. Detera-Wadleigh SD, McMahon FJ. G72/G30 in schizophrenia and bipolar disorder: review and meta-analysis. Biol Psychiatry. 2006;60(2):106-14.

80. Sacchi S, Binelli G, Pollegioni L. G72 primate-specific gene: a still enigmatic element in psychiatric disorders. Cell Mol Life Sci. 2016;73(10):2029-39.

81. Goldberg TE, Straub RE, Callicott JH, Hariri A, Mattay VS, Bigelow L, Coppola R, Egan MF, Weinberger DR. The G72/G30 gene complex and cognitive abnormalities in schizophrenia. Neuropsychopharmacology. 2006;31(9): 2022-32.

82. Ishiwata S, Hattori K, Sasayama D, Teraishi T, Miyakawa T, Yokota Y, Matsumura R, Yoshida F, Nishikawa T, Kunugi H. Plasma and cerebrospinal fluid G72 protein levels in schizophrenia and major depressive disorder. Psychiatry Res. 2017;254:244-50. 
83. Rietschel M, Beckmann L, Strohmaier J, Georgi A, Karpushova A, Schirmbeck F, Boesshenz KV, Schmal C, Burger C, Jamra RA, et al. G72 and its association with major depression and neuroticism in large population-based groups from Germany. Am J Psychiatry. 2008;165(6):753-62.

84. Wright MC, Son YJ. Ciliary neurotrophic factor is not required for terminal sprouting and compensatory reinnervation of neuromuscular synapses: reevaluation of CNTF null mice. Exp Neurol. 2007;205(2):437-48.

85. Wright MC, Wha-Ja C, Young-Jin S. Distinct patterns of motor nerve terminal sprouting induced by ciliary neurotrophic factor vs. botulinum toxin. J Comp Neurol. 2010;504(1):1-16.

86. Garcia N, Santafe MM, Tomas M, Priego M, Obis T, Lanuza MA, Besalduch N, Tomas J. Exogenous ciliary neurotrophic factor (CNTF) reduces synaptic depression during repetitive stimulation. J Peripher Nerv Syst. 2012;17(3):312-23.

87. Gu YL, Gao GQ, Ma N, Ye LL, Zhang LW, Gao X, Zhang ZB. CNTF protects neurons from hypoxic injury through the activation of STAT3pTyr705. Int J Mol Med. 2016;38(6):1915-21.

88. Druzhkova T, Pochigaeva K, Yakovlev A, Kazimirova E, Grishkina M, Chepelev A, Guekht A, Gulyaeva N. Acute stress response to a cognitive task in patients with major depressive disorder: potential metabolic and proinflammatory biomarkers. Metab Brain Dis. 2019;34(2):621-9.

89. Alpar A, Zahola P, Hanics J, Hevesi Z, Korchynska S, Benevento M, Pifl C, Zachar G, Perugini J, Severi l et al: Hypothalamic CNTF volume transmission shapes cortical noradrenergic excitability upon acute stress. EMBO J. 2018;37(21):1-23.

\section{Publisher's Note}

Springer Nature remains neutral with regard to jurisdictional claims in published maps and institutional affiliations.

Ready to submit your research? Choose BMC and benefit from:

- fast, convenient online submission

- thorough peer review by experienced researchers in your field

- rapid publication on acceptance

- support for research data, including large and complex data types

- gold Open Access which fosters wider collaboration and increased citations

- maximum visibility for your research: over $100 \mathrm{M}$ website views per year

At $\mathrm{BMC}$, research is always in progress.

Learn more biomedcentral.com/submissions 